\title{
Education and Conduct Based on Holy Quran`s Approach
}

\author{
Azam Rejali \\ Department of Theology, Isfahan (Khorasgan) Branch, Islamic Azad University, Isfahan, Iran \\ a.rejali@khhuisf.ac.ir

\section{Sayyed Hossain Vaezi}

Department of Theology, Isfahan (Khorasgan) Branch, Islamic Azad University, Isfahan, Iran

Doi:10.5901/mjss.2014.v5n20p1277

\begin{abstract}
Human as the perfect creature of having divine attributions and also as a reflection of divinity's virtue can reach the divinity's Wilayeh position and can arrive to the unity's stage in the next step. The objective of this study is the elaboration and illustration of "a journey to the love stages" based on Qoran's verses and the mystical interpretations like "Tafsir (Interpretation) of Maqzan Al- Erfan". This is a descriptive-analytic research which its findings refer the stages of mystical journey till the final stage of arriving to the theophany stage. In fact this human's journey is to meet the creation's purpose which necessitate having the conditions like belief, purity, and doing away the faults by repentance, charity-giving, and decency. Some of its stages include piety, hope, patience, morality, and contemplation. Some of the Salek's1 states at the beginning of the journey include devotion, love, and certainty. The final stages of this journey include truth, self-pleasing, surrender, theism, and doom. This journey shall be done step by step to reach the target.
\end{abstract}

Keywords: education, Seir o Soluk2, Theism, Journey

\section{Introduction}

God Almighty is a knowledgeable creator, so all of his deeds are purposeful. Obviously, the creation of this world cannot be causeless or vain. Perhaps the purpose of the world's creation could be classified into two categories: the main and the underpants. The main purpose is reaching his holy essence and virtue and the subordinate purpose is to reach the perfection status and receiving more virtue. Based on these categorizations, the purpose of human 's creation is reaching the perfection which is meeting Allah. Thus, human is a passenger, who is supposed to move from the worldly and earthen multiplicity to the divine unity and live in different stages, and then pass to arrive the unity and theism 's city. Then human being in this level is God's substitute on the earth. This journey is not going to be done physically, but passing this mystical route and reaching the target would be possible by passing the inner or intrinsic route and reaching the extremity of thralldom and monotheistic. The passenger in this journey is the human's essence whose destination is reaching the unity court and moving from multiplicity to unity. In order to pass these stages, like reaching every other target, it is necessary to meet the requirements or removing the barriers. These requirements include providing journey`s provision include belief, purity, sincerity, and doing away the faults and worldly temporal dependencies which done by awareness and repentance.

Also barriers of Soluk ${ }^{3}$ should be removed which can be possible by decency; then in the next step the journey will start. The stages and stations that should be passed in this journey are as: piety, fear, hope, humbleness, patience, selfpurification, meditation, God's remembrance, and God-fearing. The main principles in love city classified into two groups: the first category include the states that some of which occurs at the beginning of the journey like: devotion, love (the highest level of joy of closing to God), science, wisdom, certainty, and some other states which occurs toward the end of the journey which include some stages like trust, self-pleasing, appreciation, surrender, theism, and doom. At last, reaching the Wilayeh's position and the state that "what they want, will happen" would occur and the Salek would be the divine's substitute on the earth. (Amin, Seir o Soluk)

\footnotetext{
${ }^{1}$ A real God believer who devotes him/herself in the path of God

2 The journey toward God

3 The love journey toward God
} 
Human will reach a status that can see nothing but God, see that how great is humanity`s position (Sa 'di, 18)

\section{Human`s Journey, Meeting the Creation`s Target}

According to the holy Quran`s verses, human being is made of divinity`s spirit.

"And breathed into him a spirit from my presence" (Al- Israa, 70)

The secret of "breathing into" which exists in human soul means that he is accompanied with the Great God. (Shafiee, 2000) God.

Passing Seir o Soluk stages is required for reaching perfection status. So, passenger is having a journey toward

"Verily, to Allah we belong and to him we shall return" (Al- Baqarah Surah, 156)

Salek started this journey unwantedly and is going to have the most fruitful journey to reach his target which is meeting Allah. The Salek`s provision is piety, God-considering, God-remembrance, and having the ability to expulse his enemy.

The path that this Salek is going to pass is really dangerous. It is as if that it has lots of valleys, mountains, precipices, and countless domes. Salek would be outfitted by God-remembrance so repeatedly seeks God's aid. Obviously passing this route is not easy due to encountering lots of problems. Therefore its passage would not be possible except by following Sharia 4 .

When the Salek contemplates deeply, s/he will find the answer of questions like: Why I was born? Where I come from? And where am I going to?

Surely the journey to the love city would not be possible except by being God's surrender and obeying Sharia, because the best Salek's helper are religion and Sharia. Verily it includes the most complete virtues which belong to the last complete religion. One of the most important condition of stepping into Sharia's path is to have sincerity in faith which finally leads to bliss, happiness, and prosperity.

Due to boosting the human`s soul, which is all human's truth and reality, and also based on Quran's recommendations, it is necessary to pass Seir o Soluk stage.

On the other hand, it is obvious that the first on who loves the world is God himself who deserves to be noticed and loved (because he is the resource of all virtues.) the target of this love (God) is to devote himself in the path of his love; this is why he creates the world.

Based on Moslem`s prophet, Mohammad (PBUH), "God made human being of his own soul" (Ibn- Arabi). It is possible to conclude that God loves human more than the other creatures

"I was a hidden treasure and I wanted to be known, therefore I create them to be known by knowing themselves.

(Yousef Al- Haj, 2004)

the relationship of this love and his lover (human being) is in a way that he guides human being, show them the straight path and free them of his word's bondage just for the sake of love and the favor that he has toward them.

"And the book is revealed and written in a published parchment" (Al- Tur Surah, 3)

Therefore the holy books are those letters that the love (creator) send to lover (server), to sign the eternal freedom 's sentence in a way that s/he could reach the position of "In the Omnipotent Sovereign" (Al- Qamar Surah, 55). Holy Quran is the most complete and the greatest letter. This is why he has shown and explained his signs to the human being from stage to stage and teaches him in order to lead him/her in the right path. The creator included the state of "requiring perfection status" in the human essence. Therefore it is necessary to pass the love cities and pray the morality's pearl of the love and wisdom 's ocean (i. e holy books, specially the Holy Quran).

If human being is really searching the reality to reach the perfection status, then s/he should start searching his/her own faults to do them away.

As Mohammad (PBUH) said: "if a person knows him/herself, verily s/he will know God" (Gheisari, 1999)

\footnotetext{
4 Islamic Laws
} 
With the existence of theology and prosperity's enthusiasm, human being would get happier when s/he finds his/her own faults, because it cause him/her to get closer to God. Then the requirements of reaching to the target will be met for Salek. What is necessary for Salek in this journey to reach is as provision, barriers, and the journey`s necessary principles which will be defined as follows:

\section{The Passenger`s Provision}

The necessary starting for Seir o Soluk is that human being find him/herself as an immature creature who should be completed and need provision and a guide. Clearly if a person does not know that $\mathrm{s} / \mathrm{he}$ is a passenger, no change will happen. Therefore, if a person starts this big journey, it is vitally important for him/her to be careful regarding some affairs to reach the desirable purpose.

\section{1 providing the conditions}

\subsubsection{Belief}

The word "belief" means "to move to the direct path, give someone the opportunity, or to ensure somebody and accepting Sharia". It will be done by confessing by tongue in religion, performing by body organs, and belief by heart (Saeidi, 2004). Thus belief is a primary requirement of the journey which considered as the journey`s provision (Allahverdikhani, 2002). It is up to the passenger of this route to have a trial over providing journey`s provision.

"Allah is the guardian of those who believe. He takes them out from the darkness into the light" (Al- Baqarah Surah, 257)

The effects of believing God include worldly and hereafter effects. The temporal and worldly effects related to this world that we live on, and the hereafter effects related to spiritual relationship and by-heart belief.

Salek's process will not be done belief's stability and heart's belief. In condition that the heart, tongue, and body organ`s accompany each other, the true belief occurs.

Passing the right path needs a great perseverance; the appearance of absolute goodness needs hardworking (Shafiee, 2000)

\subsubsection{Purity}

The Salek's slogan should be purity and sincerity.

"O, men! Pure religion of monotheism belongs to Allah alone" (Az- Zomar Surah, 3). The Allah`s religion is something which is devoid of hypocrisy and egocentric. This kind of religion just belongs to Allah. When a person wants to overcome his/her concupiscence some barriers should be passed. Self-purification is the first and the best solution to overcome it. Normal people who say "yes" to lusts cannot purify themselves; such people cannot overcome the barriers to reach the target. Sincerity here means that all of Salek's actions should be in the path of closing to God, and nothing else, because every worldly purpose is considered as hidden atheism. Also, a sincere person does not believe that this good deed is what s/he has done, but the real believer that confesses that they are just God gift. This is why they say "Nothing could happen without God's power and help." Undoubtedly, the good deeds like all states, actions, characteristics are getting innate in the essence of a sincere believer. An insincere Salek will not have purity virtue.

"And when the matter of war is decided, if they be truthful with Allah and do not bring false excuses for not taking part in the war, it would be best for them; because Allah knows the secret of the hearts." (Mohammad Surah, 21)

\subsection{Doing the barriers away}

\subsubsection{Repentance}

It is the second deed which Salek should take it into consideration. It means taking those affairs which prevent spiritual movement into consideration. Sins and faults are those obstacles which should be removed by repentance. If they do not repent, they cannot continue this journey. 
"And those who do not desist are the wrong doers" (Al- Hujurat Surah, 11)

Doing the obligatory deeds and preventing the forbidden deeds is necessary for Salek. Repentance awaken the human`s spirit to stop the wrong actions that have been committed. It is in a way that this person decisively decides not to repeat the wrong action.

Repentance is one of the greatest human's status and is the only human's salvation and temporal and hereafter promotion which its truth is clearing and removing the faults. The barriers of this journey are not taking charity-giving and self-restraint or decency.

"and for Allah's pleasure they feed the needy, the orphan, and the captive though themselves go hungry." (Al- Insan Surah, 8)

Being kind with God`s creatures is the principle of believers' live (Shafiee, 2000)

"And say to the believing men not to stare in the women's eyes and that they should have control over their carnal desires ... and say to the believing women that they should not stare in the men's eye and they should subdue their carnal desires" (An- Nur Surah, 31)

\section{The Journey`s Stages}

Salek is ready to move of the removing barriers and provide the conditions. This world is like a bridge to reach the hereafter. Human should stop into the belief's path and remove he barriers of the journey.

If you could stop providing your desires, you can remove your heart's miff (Rumi, 2010)

\subsection{Piety}

By taking this fact into consideration that one of the biggest barriers of this journey is the lusts. It is possible to account piety as the first step of this journey. (Allahverdikhani, 2002)

"The rest of the capital which is left with you by Allah's favor for you if you are believers." (Hud Surah, 86)

The really important factor for the believers is to leave the treasures of this world because they should be spent for providing a good destiny.

If your great wish is meeting God, why you are so proud in this world (Shafiee, 2000)

\subsection{Being fearful}

This stage happens after piety. It is necessary to fear God.

"They fear from the disobedience of their creator and nurturer who is above them" (An- Nahl Surah, 50)

This fear is for future while sorrow and despondency is about the past. The highest level of fear is the fear of being far from God or the fear of the existence of the obstacles for meeting Allah. None of the stages can eradicate the joy of sins and lusts but God-fearing. Fear is not enough alone, because sometimes it might be out of patience. It usually needs to be followed by hope.

\subsection{Hope}

It refers to the happiness of waiting to meet God (Sheikh Al- Islami, 2004). This happiness occurs when the passenger provide the condition to meet God. (Kashani, 1993)

"Indeed the messenger of Allah is an outstanding exemplar for those who have hope in Allah's Grace and in the Last Day and who keep on saying Allah's remembrance" (Al- Ahzab Surah, 21) 


\subsection{Patience}

It is a sign of loving the lover in a way that the love enjoys harnesses in the path of reaching the target.

"O, Messenger! Be patient, since your practice is for Allah's way and you will surely be aided by Allah." (An- Nahl Surah, 127)

Since patience needs a great power, it should be invoked of God.

"That all power belongs to Allah" (Al- Baqarah Surah, 165)

If a person would not be helped and confirmed by God, verily s/he could not be patient.

\subsection{Morality}

The fundamental human`s pectoral need is self-purification which lead to have good moral.

"As for him who spends in charity and fears from the disobedience of Ahhah's command, and confirms the truth of the supreme excellent [the Holy Quran or the paradise], we will solve his problems and will make his difficulties to encounter with easiness" (Al- Layl)

\subsection{Contemplation}

It is one of the necessary duties of the passenger of God, because stopping contemplation and thinking prevents God's remembrance. This virtue is recommended in Quran a lot.
"We have sent down to you this holy Quran that you may explain to the people clearly what is sent down of the divine decrees in order that they may ponder" (An- Naml Surah, 44)
Contemplation is the God-remembrance prerequisite (Amin, Maqzan Al- Erfan)

\section{The Love Cities Principles}

God-fearing is the love`s gate key. The next movement would be done after piety.

"So, take a provision with you, and verily the best provision is piety" (Al- Baqarah Surah, 197).

After this stage Salek will pass the love city, allies, and houses by God's help. The next stage is principles including Salek`s states from the beginning to the destination.

\section{The States of the Salek's Journey}

\subsection{The first state of this journey: these states include the followings:}

\subsubsection{Devotion and love.}

The word "Erade" means "intention", "tendencies", or "to want" and here means self-satisfaction in order to abandon and forget about the wishes and pay attention to God's orders and then satisfy by them. (Goharin, 1988). The word "Mohebbat" means "to love" and here means to be joyful of something. It is in a way that love adores God by heart and would like to do everything in the path of God even to doom. (Saeidi, 2005) which is a state of Salek`s position.

"Should know that Allah will bring a people whom Allah is affectionate toward them and above all, they love Allah" (AlMa idah Surah, 54)

One of the most important requirements of moving toward Allah is to love him.

If you do not love someone, your trial and deeds will not be credible. (Shafiee, 2000)

Verily love is one of the wisdom's effects, this love is instinctive. 9Dinally, 2008) 
"And when they hear what has been sent down to the messenger, you will see their eyes overflow with tears on account of what they recognize of the truth." (Al- Ma idah Surah, 83)

The fact is that if wisdom does not exist, certainly love will not exist too, without love meeting God is impossible. The rule is as the condition that if the love is in its best characteristics and it has been discovered by love, then the love is going to love deeply his/her lover, it is because of being aware of his goodness. Therefore, love is wisdom's fruit and wisdom is the reason of love. (Ebrahimi Dinani, 2008)

\subsubsection{Certainty}

The word "Yaghin" is a knowledge which is doubtless and here means "to believe by heart, not by logic or reasoning." It is the best way for Salek to tolerate the journey`s hardness.

"And on the earth are signs of Allah's power for people who believe with certainty." (Az- Zariyat Surah, 20)

\subsection{The states which happen at the end of the mystical journey}

Those states which occur within reaching the "meeting Allah's status" specially toward the end of the journey are as: Trust, self-pleasing, surrender, theism, and doom.

\subsubsection{Trust.}

Confessing the inabilities and insufficiencies in all affairs and separating from all, except God. (Allahverdikhani, 2002)

"And put all your trust in Allah, if you are believer." (Al- Ma idah Surah, 23)

If I do not have anything except "trust to God", I will make sure that I have everything. (Shafiee, 2000)

\subsubsection{Self-pleasing.}

It is another state of a Salek

"Return to your creator and nurturer well-pleased yourself and well pleasing to Allah." (Al- Fajr Surah, 28)

The satisfaction status is well pleasing regarding to what God provides with us. The desire of normal and superficial people is that they well-pleased God for not punishing in the day of doom, but the ideal desire of thoughtful people is that God well-pleased them and in every condition including: death or live, doom or eternality, hardship or ease, and every other hard circumstance they praise God, because they know that God cause and want all of these things happen to them. (Allahverdikhani, 2002)

\subsubsection{Submission.}

This status stands above trust. In the later Salek asks God to help, but in submission, Salek believes that everything is done by Allah and none of them would be done by Salek.

"No, by your creator and nurturer! They will not be considered believers, unless they accept you as a judge in all that they dispute among themselves; and also if they do not find in their souls any resistance against what you decide, they submit themselves with total submission to your judgment." (An- Nissaa Surah, 65)

Also, submission level stands above well-pleasing status too; because in well-pleasing status Salek agrees with God's order, but in submission status Salek will not agree or disagree, because everything (good or bad) will determine by God, not human.

If someone asked you "what is live?" say it is submission, every submitter is a g to disregard the wishes and just real love (Rumi, 2010) 


\subsubsection{Theism}

It is one of the last stages that Salek passes. Theism is to purify the self for God and separate from what is not related to God. It means to disregard the wishes and just pay attention to God.

"Allah himself bears witness that there is no God but Allah." (Al- e - Imran Surah, 18)

The greatest theism status is meeting Allah. When Salek reaches this status, it means that s/he has doomed at the end of the journey or movement.

\subsubsection{Doom}

It is a state that the self does not have "will" and want what God wants.

"Only the existence of your creator and nurturer is the eternal, the one who is the source-owner of sublimity, honor, and beauty." (Ar- Rahman Surah, 27)

Forget about the world of duality, just think about unity, in a unity position you will certainly have love and you would be love (Shafiee, 2000)

The word "Fana" means "to doom" and here means "the server's doom for tor God." It also means the doom, faulty and condemned characteristics and the eternity of acceptable ones. (Sajjad, 1998) one of the doom's result is Wilayeh. When a Salek reach this stage s/he would be close to God in a way that reach the Wilayeh or the "Be! And it come to existence" status, because this person is God`s substitute.

\section{Conclusion}

The purpose of creation is human's existence which everything has been created for the sake of him. The purpose of human`s creation is the extreme wisdom to God`s essence and characteristics. Just human can know God.

"We did not indeed offer the trust to the heavens, the earth, and the mountains but they fearing that they may not be able to meet the due responsibility did not undertake it." (Al- Ahzab Surah, 72)

If human being could pass all of the needed stages and purify his own soul and spirit he can truly and really knows God, the responsibility that just human can undertake, not any other creature. Obviously passing these stages required human being to separate from everything and pass the Sharia, Tariiqat, and reality path. Reaching God can be possible through passing lots of routes. The stages of this journey can be passed with joy and love. Certainly when the love was not the God`s surrender, the love status would not be met. This spiritual journey is a movement from multiplicity to divine unity which is the particular status of Salek who passes the love stages one after another to reach the theism 's best level to say "There is no God except Allah."

\section{References}

Allahverdikhani, A. (2003). A journey to Kaabe Janan. (2nd ed.). (Vol. 1). Tehran: Tehran University Publication Ebne Arabi, M. The Mecca`s occupations. Beirut: Dar Sader Publication Ebrahimi Dinani, G. (2004). The wisdom`s notebook and the love sign. (2nd ed ed.). (Vol. 2). Tehran: Tarhe No Publication Gheisari, D. (1995). Interpreting Ibn Arabi’s Fosoos Al- Hekam. Beirut: Anvar Al- Hoda Publication Goharin, S. S.(1988). On the definition of Tasavof Terms. (1st ed.). Tehran: Golshan Publication Hafez, S. M. (2011). Divan Hafez. (3rd Ed.). Tehran: Arghavan Publication Holy Quran Kashani, A. (1993. An interpretation of Mnazel Al- Saerin. (1st ed.). Qom: Bidar Publication Molavi, J. M. (2004). Spiritual Mathnavi. Ghaara, A. \& Ughloo, E (Eds.). Ghunie: Ghunie Municipalitys Publication Molavi, J. M. (2010). Divan Shams Tabrizi. (2nd ed.). Tehran: Association of Cultural Works Publication Nosrat, A. Maqzan Al- Erfan. Esfahan: Neshat Publication Nosrat, A. Seir Soluk. (3rd Ed.). Esfahan: Ferdowsi Publication Saeidi, G. (2005). Ibn- Arabi dictionary of mystical terms. (2nd ed.). Tehran: Shafiee Publication Sajjadi, S. J. (1996). Dicctionary of mystical terms. (3rd ed.). Tehran: Golshan Publication 
Se`adi, M. Koliat Sa`adi. Forughi, M. (Ed.). Tehran: Miad Publication Shafiee, H. (2000). The house of love. (1st ed.). Tehran: Hamshahri Publication

Sheikh Al Eslami, A. (2003). The principles of the stages. (1st ed.). Tehran: Tehran University Publication

Yousef A- Haj, A. (2003). Mosue, Al- Ahadith Al-Qidsie Al- Sahiha and Al- Zaeifa. (1st ed.). Damesqas: Maktabat Ibn Hejr Publication 